\title{
Recent variations of calving glaciers in Patagonia, South America, revealed by ground surveys, satellite-data analyses and numerical experiments
}

\author{
RENJI NARUSE, \\ Institule of Low Temperature Science, Hokkaido University, Sapporo 060, Japan \\ Masame ANiYa, \\ Institute of Geoscience, University of Tsukuba, Ibaraki 305, Japan \\ PEDRO SKVARCA, \\ Instituto Antártico Argentino, Cerrito 1248, 1010 Buenos Aires, Argentina \\ Gino Casassa \\ Centro Austral Antártico, Universidad de Magallanes, Casilla 113-D, Punta Arenas, Chile
}

\begin{abstract}
Large retreats were revealed for most glaciers in Patagonia, South America, by analyzing satellite images and air photographs. For example, Glaciar O'Higgins retreated $13 \mathrm{~km}$ during 41 years from 1945 to 1986 and Glaciar Upsala retreated about $3 \mathrm{~km}$ between 1968 and 1990. During the 41 years former period, however, the southern tongue of Glaciar Pio XI advanced by up to $8.5 \mathrm{~km}$ and Glaciar Moreno remained almost in a steady state. Considerable ice-thinning rates, from 3.0 to $11 \mathrm{~m} \mathrm{a}^{-1}$, were measured by surveying surface profiles in the ablation areas of Tyndall and Upsala glaciers, respectively, during the period from 1985 or 1990 ) to 1993. The ice thickness of Glaciar Moreno, however, has changed very little.

Numerical experiments using a simple mass-balance model show that a $100 \mathrm{~m}$ rise in the equilibrium-line altitude due to climatic change would result in about a 200 $350 \mathrm{~m}$ rise in the frontal altitude at Glaciar Lpsala corresponding to a retreat of $58 \mathrm{~km}$, while it would cause only about a $70-100 \mathrm{~m}$ rise at Glaciar Moreno. The large difference between these two neighbouring glaciers results from the difference in contributions of the calving amount to the total mass balance, as well as the difference in the altitudinal distributions of drainage areas.
\end{abstract}

\section{INTRODUGTION}

Two vast ice-covered regions exist in Patagonia, the southern part of South America. The larger one is Hielo Patagónico Sur (HPS; southern Patagonia ice field) with an area of $13000 \mathrm{~km}^{2}$, and the smaller one Hielo Patagónico Norte HPN; northern Patagonia ice field covering $4200 \mathrm{~km}^{2}$ (Figs 1 and 2). A number of glaciers discharge radially from the ice fields. Most of the outlet glaciers calve into fjords on the western sides of the ice fields and into lakes on the eastern sides. Although no detailed quantitative estimates have been given as to the entire mass balance of the ice fields and glaciers, Patagonian glaciers are seen as representing typical temperate characteristics, with large amounts of accumulation, melting and calving throughout the year. Not only in the temperate, but also in polar regions, numerous tide-water glaciers terminate in the ocean with calving of icebergs. Since the cyclic advances and retreats of grounded tide-water glaciers are not related to climatic fluctuations in a direct way (Meier and Post,
1987), studies of variations and dynamics of calving glaciers are greatly needed.

Before 1980, glaciological research in Patagonia consisted of preliminary studies or inventory work (Lliboutry, 1956; Bertone, 1960). Glaciar Pio XI (or Brüggen) in HPS has been noted for frequent fluctuations of its frontal position and was studied recently by Rivera (1992). In the summers of 1983/84, 1985/86, 1990/91 and 1993/94, extensive glaciological and meteorological studies were carried out on outlet glaciers of HPN and HPS as joint projects of Japan with Chile and Argentina (Nakajima, 1987; Naruse and Aniya, 1992).

This paper presents recent variations of outlet glaciers obtained from these ground surveys and from analysis of satellite images and air photographs taken during the last 50 years. When we discuss the role of glaciers in driving and responding to global change based on frontal variations and/or thickness changes in Patagonia, we should evaluate the contribution of calving amount to the mass balance of a glacier and estimate the change in 


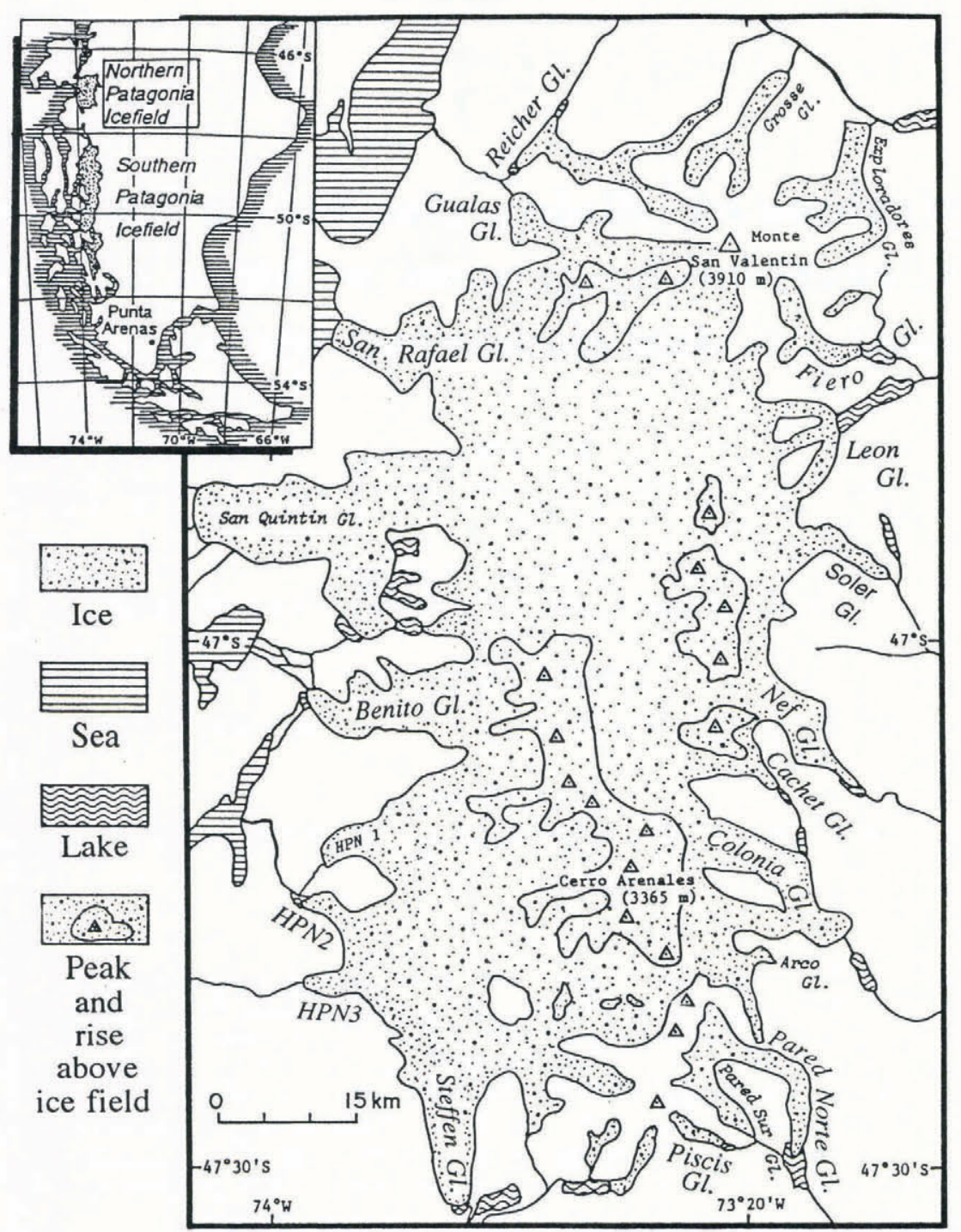

Fig. 1. Hielo Palagónico Norte (HP.N) and outlet glaciers.

calving rate as the glacier fluctuates. Therefore, in order to make clear the characteristics of calving glaciers and the sensitivity of their variations, numerical experiments were conducted on frontal variations of Upsala and Moreno glaciers with a simple mass-balance model, and the results are given.

\section{DATA SOURCE AND SURVEY METHOD}

\section{Remote-sensing data}

For HPS the most complete set of satellite data for the purposes of the present study are Landsat TM images taken on 14 January 1986; these clearly show all the outlet glaciers around HPS with few clouds. For the northern half of HPS, Landsat MSS data taken on 25 February 1976 are available without clouds. These data are supplemented by the Salyut-6 (1978), Landsat RBV (1979), SPOT HRV (1987) and SPOT P (1991) images.

For other periods and areas than those listed above, data utilised included U.S. trimetrogon air photographs taken in 1944 45, and vertical air photographs taken between the late 1960s and early 1980s by Argentine and
Chilean organizations. Oblique air photographs were also taken around the periphery of HPN in 1985/86 and 1991/ 92 by Aniya (1988, 1992a). Using these data, limits of outlet glaciers of HPN and HPS were digitized. By superimposing one image of a glacier on another from a different year, variations of the front position and surface area were measured (Aniya and others, 1992).

\section{Glacier surface elevations}

Surface elevations of bare ice in ablation areas were measured on four glaciers in Patagonia using conventional survey methods with an electronic distance meter during the period 1983-93. Surface profiles were determined along a $1.5 \mathrm{~km}$ long medial moraine in the lower part of Glaciar Soler; a $5 \mathrm{~km}$ long transverse line at $15 \mathrm{~km}$ from the front of Glaciar Tyndall; a $1.5 \mathrm{~km}$ long transverse line near the front of Glaciar Upsala; and a $3 \mathrm{~km}$ long cross about $5 \mathrm{~km}$ from the front of Glaciar Moreno (Naruse and Aniya, 1992). From a pair of elevation data measured in different years relative to the same control station on the bare rock, changes in ice thickness were obtained Aniya and Naruse, 1987; Kadota and others, 1992). 


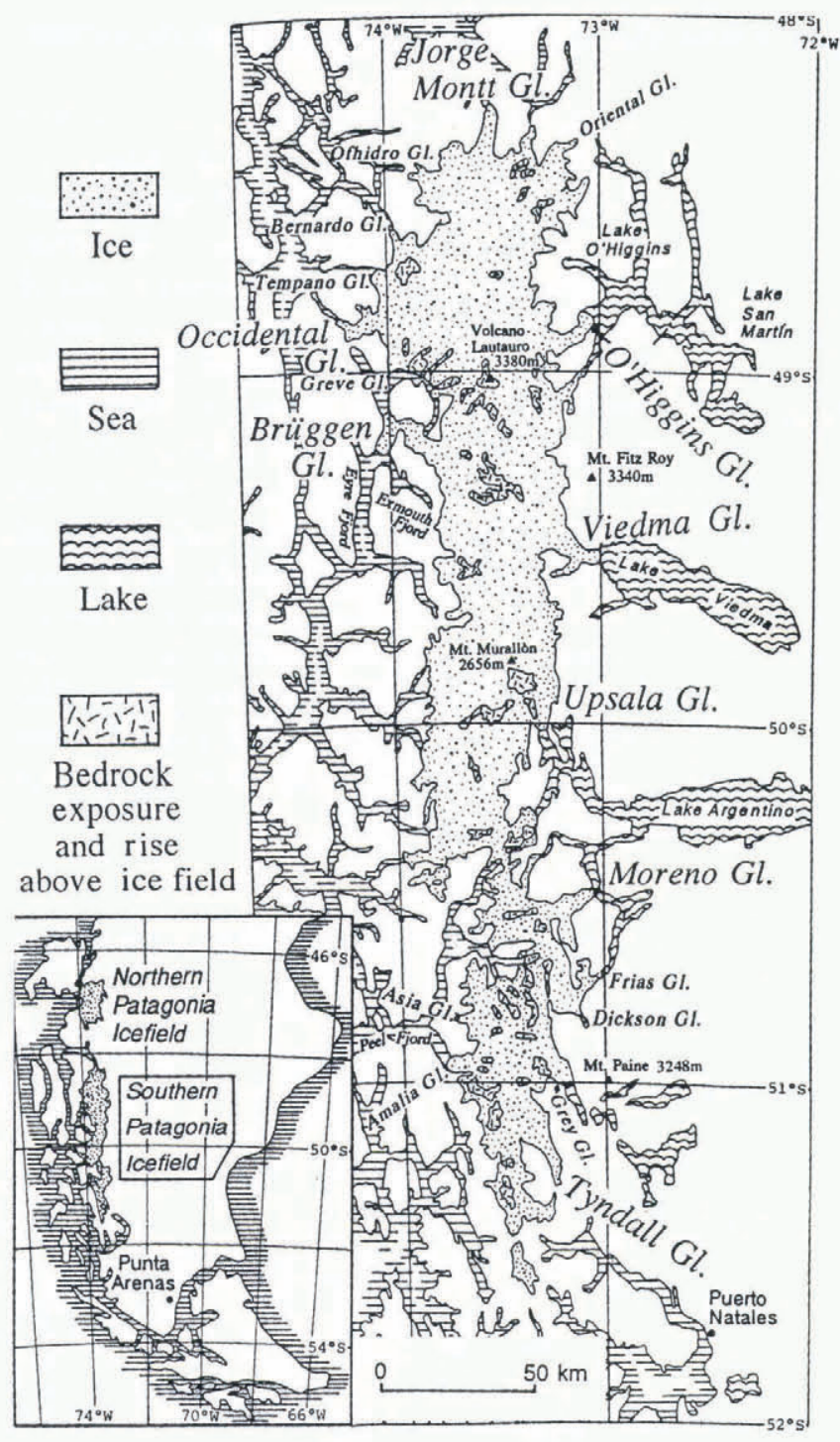

Fig. 2. Hielo Palagónico Sur (HPS) and outlet glaciers.

\section{REGENT GLACIER VARIATIONS}

\section{Frontal variations}

From the analyses of remote-sensing data, half of the 28 outlet glaciers in HPN (Fig. 1) were found to have been calving into fjords or lakes in the early 1940 s, and these are regarded as calving glaciers in this paper, though some of them have since retreated, and their present fronts are far from water.

Variations in the frontal positions of the 14 calving glaciers between 1945 and 1990 are shown in Figure 3 (Aniya, 1992b). Except for Reicher, San Rafael and Cachet glaciers, the tendencies of the variations are very similar, with gradual retreats of $0.5-2 \mathrm{~km}$ during the last half century. Glaciar San Rafael, the only glacier in HPN that is at present calving into a fjord, has retreated $3.4 \mathrm{~km}$ during the last 16 years. No advancing glaciers exist in HPN.

Among 19 major outlet glaciers of HPS (Fig. 2), nine at present calve into fjords and ten into lakes. Analyses were made of nine larger glaciers, and variations in their front positions between 1945 and 1990 are shown in Figure 4. A considerable retreat is observed for Glaciar

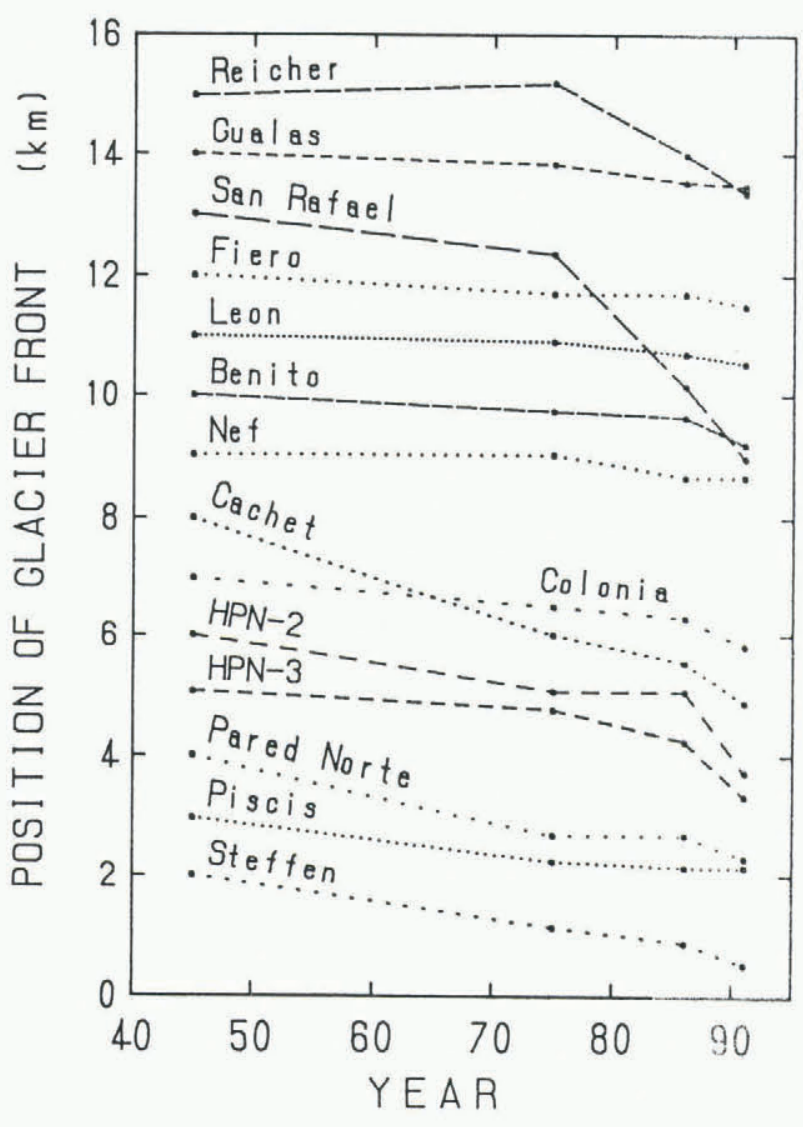

Fig. 3. Variations in frontal positions of calving glaciers in Hielo Patagónico Norte. Positive gradient of each line shows an advance, and negative a retreat. Glaciar San Rafael calves into a fjord (i.e. is a tide-water glacier) and the other 13 glaciers (fresh-waler) calve into lakes.

O'Higgins, a northeastern outlet glacier which showed a $13 \mathrm{~km}$ retreat during the last 41 years, the mean retreat rate being $330 \mathrm{~m} \mathrm{a}^{-1}$. This is about one order larger than the mean retreat rate in HPN (about $30 \mathrm{~m} \mathrm{a}^{-1}$ ). The other three glaciers in the north of HPS, Jorge Montt, Occidental and Viedma, have been retreating gradually at the same rate as in HPN. Upsala and Tyndall glaciers in the south of HPS have retreated at higher rates.

Noteworthy is the peculiar behavior of the advancing Glaciar Pio XI which calves into a fjord. The southern tongue of the glacier had advanced $9 \mathrm{~km}$ during 31 years since 1945 and the northern tongue is still advancing. Glaciar Moreno has been almost in a steady state and reaches the opposite bank with a drainage tunnel at present.

\section{Thickness changes}

Thickness changes averaged over the survey line on each glacier are shown in Figure 5. It is found that Glaciar Moreno is in a steady state, while Glaciar Upsala has thinned considerably at a rate of $11 \mathrm{~m} \mathrm{a}^{-1}$. Compared with the thickness-change data on 28 glaciers compiled by Haeberli and Hoelzle (1993), the thickness-change rate of Glaciar Upsala is among the largest, and one order of magnitude larger than the mean rate of receding glaciers worldwide.

Detailed results of thickness changes with flow speeds 


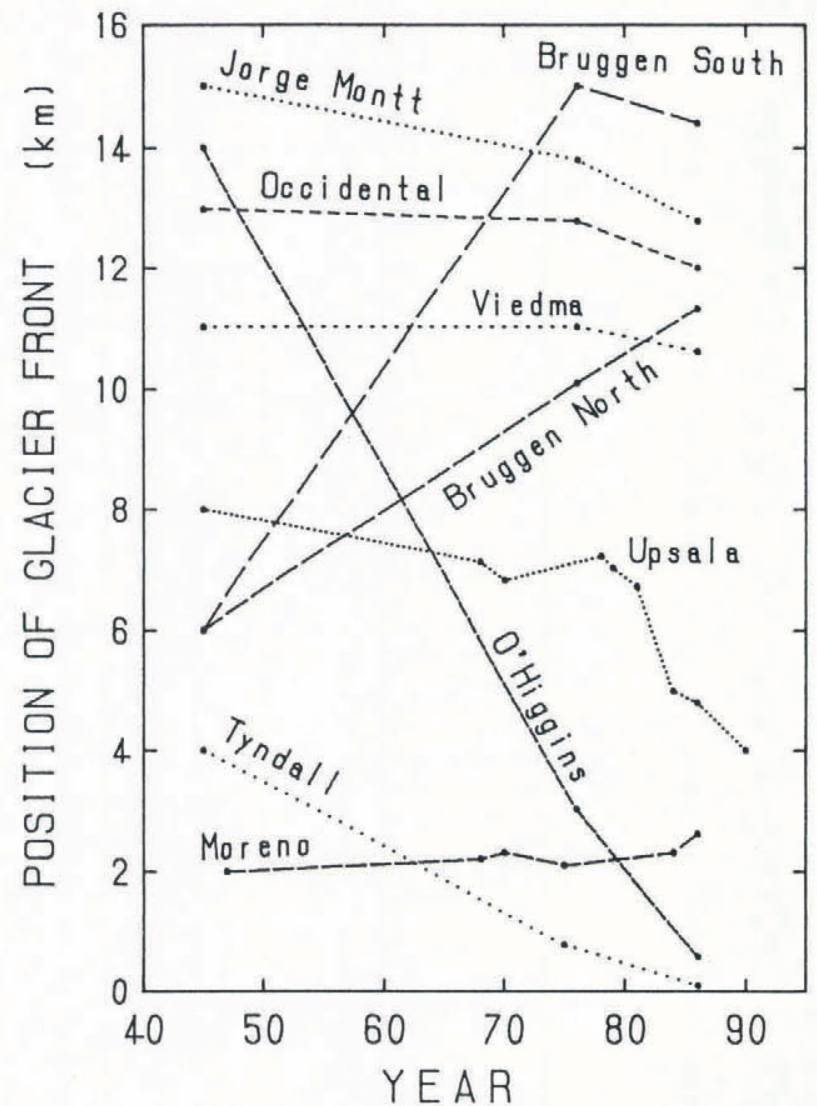

Fig. 4. Variations in frontal positions of major calving glaciers in Hielo Palagónico Sur. Positive gradient of each line shows an advance, and negative a retreat. Jorge Montl, Occidental and Pio XI (southern tongue) glaciers calve into fjords (i.e. are tide-water glaciers) and the other six glaciers (fresh-water) calve into lakes.

measured in 1993 at Upsala, Moreno and Tyndall glaciers are to be published separately (papers in preparation by R. Naruse and others; K. Nishida and others; P. Skvarca and others).

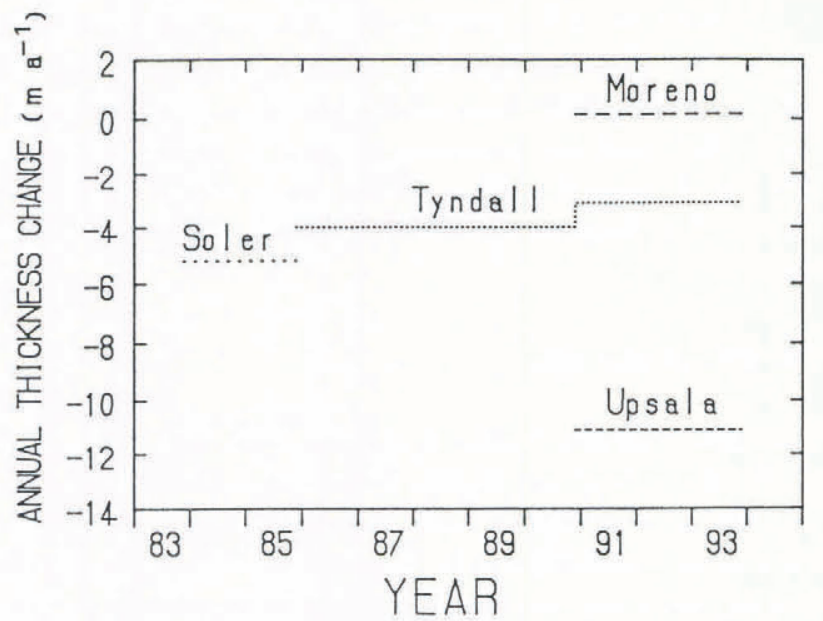

Fig. 5. Annual rates of ice-thickness change in the ablation areas of Upsala, Moreno and Tyndall glaciers in HPS. Glaciar Soler in HP.N, not a calving glacier, is also shown for comparison.
MASS-BALANCE MODEL OF CALVING GLACIER

To examine the characteristics and sensitivity of frontal variations of calving glaciers, numerical experiments are carried out for Upsala and Moreno glaciers using a massbalance model. Upsala and Moreno glaciers discharge eastwards from HPS and calve into the western ends of channels of Lago Argentino at an elevation of about $200 \mathrm{~m}$ a.s.l. The height of the calving front of Glaciar Upsala is several tens of metres above the lake level (Aniya and Skvarca, 1992), and that of Glaciar Moreno ranges from 55 to $75 \mathrm{~m}$ (Naruse and Aniya, 1992). Figure 6 illustrates altitudinal distributions of the surface areas of the two glaciers. Equilibrium-line altitude (ELA) was estimated at $1150 \mathrm{~m}$ a.s.l. at both neighbouring glaciers, based on surface features recognisable on air photographs and topographic maps (Aniya and Skvarca, 1992). The remarkable difference in distribution of glacier areas between the two may affect the different manner of frontal retreat due to a rise in ELA.

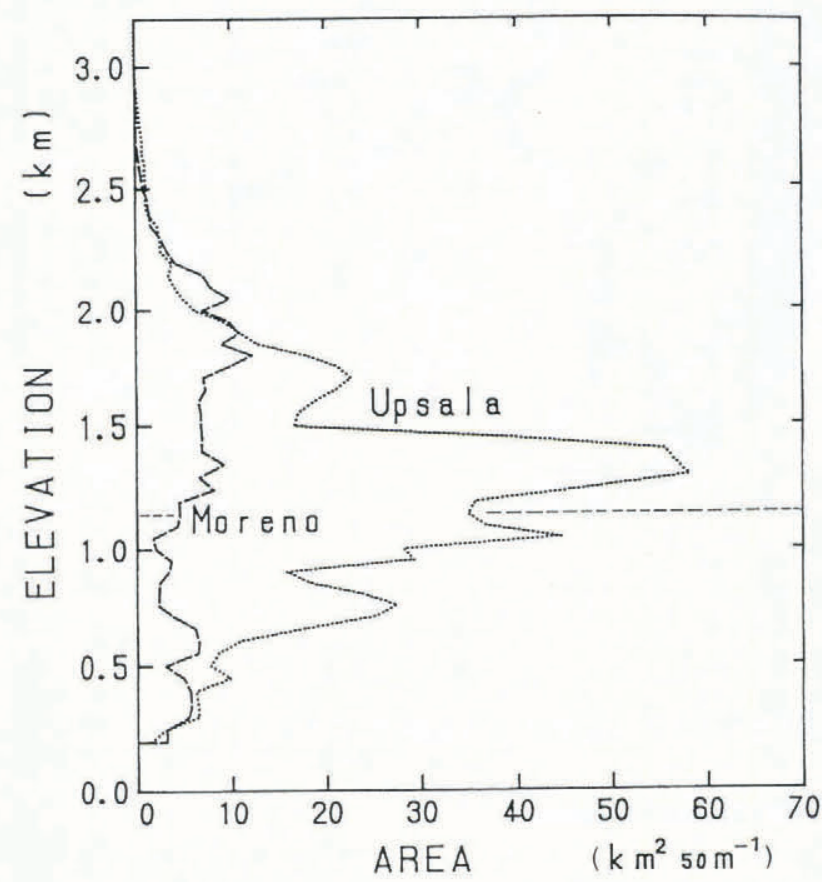

Fig. 6. Altitudinal distributions of glacier areas at an elevation interval of $50 \mathrm{~m}$, of Upsala and Moreno glaciers. The present ELA is shown by a thin broken line at $1.15 \mathrm{~km}$ a.s.l.

A mass-balance equation of a calving glacier is expressed as

$$
A-B-C=\sum a \cdot \Delta S_{\mathrm{i}}-\sum b \cdot \Delta S_{\mathrm{i}}-C=0
$$

where $A$ (and $B$ ) is the total annual net accumulation (ablation) in the accumulation (ablation) area, $C$ is the annual calving amount, $a$ (and $b$ ) is the annual net accumulation (ablation) rate measured in water equivalent in the accumulation (ablation) area, and $\Delta S_{\mathrm{i}}$ is the glacier area at an interval of a unit elevation (Fig. 6).

Here, we introduce two assumptions. First, the rate $a$ 
(and $b$ ) increases (decreases) linearly with the elevation $h$ (a.s.l.):

$$
\begin{array}{ll}
a=\alpha(h-E) & h>E \\
b=\beta(E-h) & h<E
\end{array}
$$

where $\alpha$ and $\beta$ are positive constants, and $E$ is the ELA which varies according to climatic changes.

Secondly, because the calving rate is considered to depend linearly on the water depth at the front (Meier and Post, 1987; Pelto and Warren, 1991), the calving amount $C$ decreases linearly with the elevation of the glacier front $H$. Hence,

$$
C=C_{0}(500-H) / 300, \quad 200<H<500 \mathrm{~m}
$$

where $C_{0}$ is the present rate of calving. This equation is introduced because the surface elevations about $8 \mathrm{~km}$ from the present fronts of $\mathrm{U}$ psala and Moreno glaciers are about $300 \mathrm{~m}$ higher than the lake level, and ice thicknesses are assumed to be $300 \mathrm{~m}$ with the downhill bedrock slopes.

Next, to determine the parameters $\beta$ and $\alpha$, we estimate the annual amounts of ablation and accumulation at the two glaciers. In the summer of 1993/94, ablation during $110 \mathrm{~d}$ was measured at Glaciar Moreno (350 m a.s.1.) as $7.0 \mathrm{~m}$ ice thickness. Using a degree-day method with this value and air-temperature data at Calafate (Station Lago Argentino), the annual ablation rate at $350 \mathrm{~m}$ elevation is estimated to be $11.2 \mathrm{mw}$ e. $\mathrm{a}^{-1}$ (paper in preparation by R. Naruse and others). Based on these numbers, $\beta$ is found to be $0.015 \mathrm{a}^{-1}$. This value is used in all calculations for both glaciers.

Information on the annual precipitation and net accumulation on glaciers is much more scarce. Although, from an analysis of a surface firn core, $1.2 \mathrm{ma}^{1}$ was reported as the net accumulation rate at $2680 \mathrm{~m}$ a.s.l. near the top of the Glaciar Moreno drainage Aristarain and Delmas, 1993), we do not consider this rate to be representative for the HPS plateau since it is too small to maintain the mass balance of a glacier in Patagonia. On the other hand, precipitation maps in Chile have been published by the Dirección General de Aguas (1987), in which an isoline of $8 \mathrm{~m} \mathrm{a}^{-1}$ was drawn over the high HPS plateau. Based on this, we first adopt $a=8 \mathrm{ma}^{-1}$ at an elevation of $2 \mathrm{kma.s.l}$. in the higher parts of the accumulation areas of the two glaciers, while $\alpha$ is taken to be $0.01 \mathrm{a}^{-1}$. From calculations of water balance with the discharge data at rivers in Patagonia, a mean precipitation over the eastern ice-covered areas of HPS was estimated as $6.4 \mathrm{ma}^{1}$ unpublished information from F. Escobar, 1992). Taking this value as the mean net accumulation rate in the accumulation areas of both glaciers, $\alpha$ is found to be $0.015 \mathrm{a}^{-1}$. We use these two values of $\alpha$ as constant parameters in the calculations for both glaciers. Estimated present amounts of mass-balance terms, $B, A, C(=a-B)$ and $C / A$ are shown in Table 1 . The values of $C$ given in the table are used for $C_{0}$ in Equation (4).

Calculations were done by the following procedure. When $E$ rises a little due to some climatic changes, the distribution of $a$ decreases according to Equation (2), and the total $S$ in the accumulation area also decreases, so that $A$ decreases. Then, $B$ is calculated using Equation (3) starting from the equilibrium line to the downstream areas until Equation (1) is satisfied. $H$ is obtained as a result, and $C$ decreases according to Equation (4) in the next step.

\section{GALCULATED FRONTAL VARIATIONS}

Figure 7 shows the variations in frontal elevations of Upsala and Moreno glaciers, caused by rises in the ELA calculated using different values of $\alpha$. A smaller value of $\alpha$ yields a smaller amount of calvings $C$, so that the retreat rates ( $\mathrm{Ul}$ and $\mathrm{Ml}$ ) are more sensitive to, and more enhanced by, changes in the ELA. In both cases, Glaciar Upsala retreats three or four times more than Glaciar Moreno. At Glaciar Upsala, an upward shift of the ELA by $100 \mathrm{~m}$ would cause about a $200-350 \mathrm{~m}$ rise in the frontal elevation, which corresponds to a frontal retreat of $58 \mathrm{~km}$, while at Glaciar Moreno it causes only about a $70-100 \mathrm{~m}$ rise in the front. During the last 45 years, Glaciar Upsala has retreated $4 \mathrm{~km}$ (Fig. 4). A retreat of about $5-8 \mathrm{~km}$ within several decades is possible for a small climatic change, i.e. an increase in air temperature by 1 or $2 \mathrm{C}$.

\begin{tabular}{|c|c|c|c|c|c|c|}
\hline & $\begin{array}{l}\text { Parameter } \\
\qquad \begin{array}{c}\beta \\
\mathrm{a}^{-1}\end{array}\end{array}$ & $\begin{array}{c}\text { Total } \\
\text { ablation } \\
B \\
\mathrm{~km}^{3} \mathrm{a}^{-1}\end{array}$ & $\begin{array}{l}\text { Parameter } \\
\qquad \begin{array}{c}\alpha \\
\mathrm{a}^{-1}\end{array}\end{array}$ & $\begin{array}{c}\text { Total } \\
\text { accumulation } \\
A \\
\mathrm{~km}^{3} \mathrm{a}^{1}\end{array}$ & $\begin{array}{c}\text { Total } \\
\text { calving } \\
C \\
\mathrm{~km}^{3} \mathrm{a}^{-1}\end{array}$ & $\begin{array}{c}\text { Calving } \\
\text { ratio } \\
C / A\end{array}$ \\
\hline Glaciar & & & 0.010 & 1.99 & 0.47 & 0.24 \\
\hline Upsala & 0.015 & 1.52 & 0.015 & 2.99 & 1.47 & 0.49 \\
\hline Glaciar & & & 0.010 & 1.13 & 0.54 & 0.48 \\
\hline Moreno & 0.015 & 0.59 & 0.015 & 1.70 & 1.11 & 0.65 \\
\hline
\end{tabular}

Table 1. Amounts of the present mass-balance terms calculated with parameters $\alpha$ and $\beta$, parameters of altitudinal distribution of annual net ablation and accumulation rates $(C=A-B)$ 


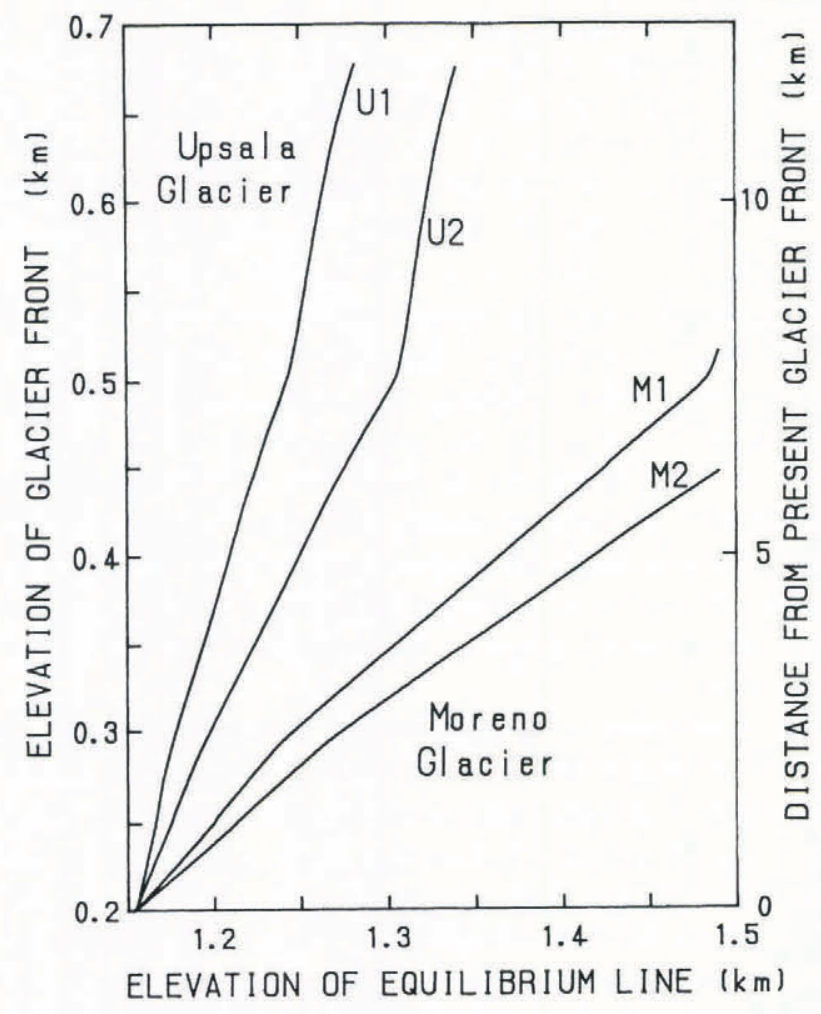

Fig. 7. Results of numerical experiments on variations in the frontal elevation caused by upward shifts of the elevation of the equilibrium line (ELA). Lines with numbers 1 and 2 attached to letters $U$ (Upsala) and $M$ (Moreno) indicate results of calculation with parameters $\alpha$ at 0.01 and $0.015\left(a^{-1}\right)$, respectively. The present fronts and ELAs of the two glaciers are located at about $0.2 \mathrm{~km}$ and $1.15 \mathrm{~km}$ a.s.l., respectively. Approximate distance from the present glacier fronts is shown in the right ordinate, being derived from the present mean surface slopes in the lower parts of the two glaciers.

\section{DISCUSSION}

\section{Features of glacier variations}

In HPS, some outlet glaciers have behaved in different manners and with different magnitudes of variations (Fig. 4). However, no clear difference was observed in tendencies of variations between the windward (western) and leeward (eastern) sides of HPS. In fact, two neighbouring glaciers calving into fjords, Occidental and Pio XI, show considerably different behaviours, as do a series of four eastward outlet glaciers, O'Higgins, Viedma, Upsala and Moreno. Therefore, we cannot attribute the retreating phenomena of most glaciers in Patagonia simply to the recent "global warming".

There are no meteorological stations in these glacier areas. Long-term meteorological data are available from Punta Arenas, about $250 \mathrm{~km}$ south of the southern end of HPS, and from Calafate about $60 \mathrm{~km}$ east of Glaciar Moreno. Although the latter station is located not too far from glaciers, the mean annual precipitation during 1981-90 was a mere $123 \mathrm{~mm} \mathrm{a}^{-1}$ (personal communication from Servício Meteorológico Nacional, 1993), indicating a very arid climate quite different from that in glacier regions. Therefore it is not easy to discuss causes or mechanisms of recent glacier variations solely on the basis of these meteorological data.

For possible mechanisms, we suggest two hypotheses here. One is related to local meteorological conditions, namely recent changes in snow accumulation and/or incident solar radiation due to changes in the predominant wind direction and/or in cloud-covered areas. A slight change in the wind regime may cause large differences in accumulation between adjacent drainages. Although we have no quantitative data, our own experience and that of local inhabitants suggest that ablation areas of eastern outlet glaciers are located around a boundary between the very humid, stormy conditions on the ice field and the dry, warm climate to the east. A slight shift of the normal position of the front of thick clouds could result in considerable change in the melting rate of ice.

Another possible mechanism is related to glacier dynamics. At Glaciar Soler in HPN, the largest flow speed was measured as about four times the smallest in summer (Naruse and others, 1992b). From this, the contribution of basal sliding to the total flow was estimated at about $75 \%$. If such a contribution varies due to a change in hydraulic conditions at the bed, the glacier may start to advance or retreat even under a steady-state surface mass balance. If the rate of calving varies as the result of changes in the level, temperature or current of water, and changes in fracturing in the ice, the glacier behaviour could also change. A large thinning rate of $11 \mathrm{ma}^{-1}$ at Glaciar Upsala may be due to such a change in the glacier dynamics.

\section{Effect of calving}

We now examine whether the present model can properly simulate the current conditions of the glaciers, by estimating approximate calving amounts at Upsala and Moreno glaciers independently of the mass-balance calculation. No measurements of ice thickness have been made at these glaciers. However, in the ablation area of Glaciar Tyndall $(8 \mathrm{~km}$ wide), a thickness of $620 \mathrm{~m}$ was measured at a point $3 \mathrm{~km}$ from the margin (Casassa, 1992). Considering the dimensions and topographies of the glaciers, it may be appropriate to suppose that the ice thicknesses near the fronts range from 300 to $500 \mathrm{~m}$ at the $4 \mathrm{~km}$ wide Glaciar Upsala and from 200 to $400 \mathrm{~m}$ at the $3 \mathrm{~km}$ wide Glaciar Moreno.

At Glaciar Upsala, an annual mean flow velocity of about $700 \mathrm{~m} \mathrm{a}^{-1}\left(1.9 \mathrm{md}^{-1}\right)$ was measured on the median line about $45 \mathrm{~km}$ from the front (Aniya and Skvarca, 1992). The product of thickness, width and annual speed gives an annual calving amount $C$ of $0.8-1.4 \mathrm{~km}^{3} \mathrm{a}^{-1}$. At the calving front of Glaciar Moreno, a flow speed of $4.4 \mathrm{~m} \mathrm{~d}^{-1}$ was measured in November 1990 (Naruse and others, 1992a). The annual mean speed is estimated as about $800 \mathrm{~m} \mathrm{a}^{-1}$, being half the summer speed (as in the case of Glaciar Upsala on which a speed of $3.6 \mathrm{~m} \mathrm{~d}^{-1}$ was measured in November 1990). Then $C$ is found to be 0.5 $1.0 \mathrm{~km}^{3} \mathrm{a}^{-1}$. These estimated calving amounts at both glaciers are within the range of $C$ in Table 1.

The great contrast in retreat rates between Upsala and Moreno glaciers seen in Figure 7 results primarily from the difference in drainage areas. In addition to this, 
due to a larger calving ratio $C /(B+C)$ at Glaciar Moreno (Table 1), a rise in the ELA that causes a decrease in $A$ causes less of a decrease in the ablation amount $B$. Consequently, the tendency of the frontal retreat is more moderate until the calving amount becomes zero at $500 \mathrm{~m}$ a.s.l. We can further suppose that the calving amount would increase, either linearly or nonlinearly, with the extension of the glacier tongue into deeper water, and would decrease with the recession of the tongue. Therefore, in an advancing stage, calving has the effect of moderating the variation of a glacier front. On the other hand, in a retreating stage, the effect is progressively weakened, so that the frontal variation becomes more sensitive to a climatic change.

\section{CONCLUSIONS}

(1) Among 22 calving glaciers of HPN and HPS studied, 20 were found to have been in retreating stages during the last half century. The retreating rate is more moderate in HPN than in HPS, with the maximum rate of $330 \mathrm{ma}^{-1}$ at Glaciar O'Higgins (HPS). However, an exceptional glacier, Glaciar Pio XI (HPS), has been advancing considerably.

(2) Retreating Glaciar Upsala (HPS) has thinned recently at a large rate of $11 \mathrm{ma}^{-1}$, while the ice thickness of nearly stable Glaciar Moreno (HPS) has remained unchanged.

(3) These glacier variations are not considered to be due to recent global climatic change alone; they may also have resulted from some changes in local meteorological conditions and/or in glacier dynamics.

(4) Due primarily to the difference in drainage areas, Glaciar Upsala retreats three or four times faster than Glaciar Moreno. For example, a rise of $100 \mathrm{~m}$ in the ELA at Glaciar Upsala may result in a rise of 200 $350 \mathrm{~m}$ in the frontal elevation, corresponding to a frontal retreat of $5-8 \mathrm{~km}$.

(5) Calving phenomena affect significantly the behaviour of a glacier, especially by moderating the variation of the front in an advancing stage.

\section{ACKNOWLEDGEMENTS}

This study was supported by grants-in-aid for research (No. 04452068) and the International Scientific Research Program (Field Research: Nos. 02041004 and 05041049), Ministry of Education, Science and Culture, Japan. We are grateful to $\mathrm{K}$. Satow of Nagaoka College of
Technology, T. Toconas of Instituto Antártico Argentino, and K. Nishida and Y. Takeuchi of Hokkaido University, for participating in the field-work, and to the Servício Meteorológico Nacional, Argentina, for providing meteorological data.

\section{REFERENCES}

Aniya, M. 1988. Glacier inventory for the Northern Patagonia Icefield, Chile, and variations 1944/45 to 1985/86. Arct. Alp. Res., 20 2), 179-187.

Aniva, M. 1992a. Glacier variation in the Northern Patagonia Icefield, Chile, between 1985/86 and 1990/91. Bull. Glacier Res. 10, 83-90.

Aniya, M. 1992b. Recent glacier variations in the Northern Patagonia Icefield, Chile, In 27th International Geographical Congress, Washington, D.C. Technical Program Abstract, 2425.

Aniya, M. and R. Naruse. 1987. Structural and morphological characteristics of Soler Glacier, Patagonia. Bull. Glacier Res. 4, 69- 77.

Aniya, M. and P. Skvarca. 1992. Characteristics and variations of Upsala and Moreno glaciers, southern Patagonia, Bull. Glacier Res. $10,39-53$.

Aniva, M., R. Naruse, M. Shizukuishi, P. Skvarca and G. Casassa. 1992. Monitoring recent glacier variations in the Southern Patagonia Icefield, utilizing remote sensing data, Int. Arch. Photogramm. Remole Sensing, 29, Part B7, 87-94.

Aristarain. A. J. and R. J. Delmas. 1993. Firn-core study from the southern Patagonia ice cap, South America. J. Glaciol., 39 132), $249-254$.

Bertone, M. 1960. Inventario de los glaciares existentes en la iertiente Argentina entre los paralelos $4730^{\prime}$ y $51^{\circ} \mathrm{S}$. Buenos Aires, Instituto Nacional del Hielo Continental Patagónico. Publicación 3.

Casassa, G. 1992. Radio-echo sounding of Tyndall Glacier, southern Patagonia. Bull. Glacier Res. 10, 69-74.

Dirección General de Aguas. 1987. Balance hidrico de Chile. Santiago, Ministerio de Obras Públicas.

Escobar, F., F. Vidal, C. Garín and R. Naruse. 1992. Water balance in the Patagonia Icefield. In Naruse, R. and M. Aniya, eds. Glaciological researches in Patagonia, 1990. Sapporo, Japanese Society of Snow and Ice, $109-119$.

Haeberli, W. and M. Hoelzle, comps. 1993. Fluctuations of glaciers 1985 1990 (Vol. VI). Paris, International Commission on Snow and Ice of the International Association of Hydrological Sciences/UNESCO.

Kadota, T.. R. Naruse, P. Skvarca and M. Aniya. 1992. Ice flow and surface lowering of Tyndall Glacier, southern Patagonia. Bull. Glacier Res. 10, 63-68.

Lliboutry, L. 1956. Viezes y glaciares de Chile. Santiago, Ediciones de la Universidad de Chile.

Meier, M. F. and A. Post. 1987. Fast tidewater glaciers. J. Geophys. Res., 92 B9), 9051-9058.

Nakajima, C. 1987. Outline of the Glaciological Research Project in Patagonia, 1985-1986. Bull. Glacier Res.. 4. 1-6.

Naruse, R. and M. Aniya. 1992. Outline of Glacier Research Project in Patagonia, 1990. Bull. Glacier Res. 10, 31-38.

Naruse, R., H. Fukami and M. Aniya. 1992b. Short-term variations in flow velocity of Glaciar Soler, Patagonia, Chile. J. Glaciol., 38 128, $152-156$.

Naruse, R., P. Skvarca, T. Kadota and K. Koizumi. 1992a. Flow of Upsala and Moreno glaciers, southern Patagonia. Bull. Glacier Res. 10,5562 .

Pelto. M.S. and C. R. Warren. 1991. Relationship between tidewater glacier calving velocity and water depth at the calving front. Ann. Glaciol.. 15, 115-118.

Rivera, A. 1992. El Glaciar Pio XI: avances y retrocesos, el impacto sobre su entorno durante el presente siglo. Revista Geográfica de Chile Terra Australis, 36, 33-62. 